\title{
PENGARUH KECERDASAN EMOSIONAL TERHADAP MOTIVASI BELAJAR MATEMATIKA SISWA KELAS IV SD NEGERI 1 NGULANKULON
}

\author{
Fitriana As Sidik \\ Program Studi PGSD STKIP PGRI Trenggalek, Indonesia \\ Email: fitrianaassidik@gmail.com \\ Efi Ika Febriandari \\ Program Studi PGSD STKIP PGRI Trenggalek, Indonesia \\ Email: efi.ika.f@gmail.com \\ Angga Setiawan \\ Program Studi PGSD STKIP PGRI Trenggalek, Indonesia \\ Email: anggasetiawan25.as@gmail.com
}

\begin{abstract}
This study aims to determine the level of emotional intelligence, find out the motivation to learn mathematics and determine the effect of emotional intelligence on motivation to learn mathematics. Using quantitative research with survey methods. Population and sample of all fourth grade students with 21 students. Data obtained by observation and disseminating the first questionnaire aims to find out emotional intelligence and the second questionnaire to determine student motivation. The research instrument uses a scale of emotional intelligence and motivation to learn mathematics. Descriptive analysis results show that the emotional intelligence of class IV students is in the medium category with a percentage of $14 \%$, while the motivation to learn mathematics in class IV is in the moderate category with a percentage of $29 \%$. After analyzing the data it is known that there is a significant influence with the results of $\mathrm{r}$ count $=16.991$ and consulted with a value of $t$ table $=1.729$. While the influence of variable $X$ (emotional intelligence) on the $Y$ variable (mathematics learning motivation) was $93.8 \%$. With these results, the alternative hypothesis is accepted and the null hypothesis is rejected. It can be concluded that there is a significant influence of the influence of emotional intelligence on mathematics learning motivation of fourth grade students of SD Negeri 1 Ngulankulon.
\end{abstract}

Keyword: Emotional, Intelligence, , Learning Motivation, Mathematics 


\begin{abstract}
Abstrak
Penelitian ini bertujuan untuk mengetahui tingkat kecerdasan emosional, mengetahui motivasi belajar matematika dan mengetahui pengaruh kecerdasan emosional terhadap motivasi belajar matematika. Menggunakan penelitian kuantitatif dengan metode survei. Populasi dan sampel keseluruh siswa kelas IV dengan jumlah 21 siswa. Data yang diperoleh dengan observasi dan menyebarkan angket pertama tujuannya untuk mengetahui kecerdasan emosional dan angket kedua untuk mengetahui motivasi belajar siswa. Instrumen penelitian menggunakan skala kecerdasan emosional dan skala motivasi belajar matematika. Hasil analisis deskriptif menunjukkan bahwa kecerdasan emosional siswa kelas IV berada pada kategori sedang dengan persentase $14 \%$, sedangkan motivasi belajar matematika siswa kelas IV berada pada kategori cukup dengan persentase $29 \%$. Setelah dilakukan analisis data diketahui bahwa adanya pengaruh yang cukup signifikan dengan hasil rhitung=16,991 dan dikonsultasikan dengan nilai tabel=1,729. Sedangkan besar pengaruh variabel $X$ (kecerdasan emosional) terhadap variabel $\mathrm{Y}$ (motivasi belajar matematika) sebesar 93,8\%. Dengan hasil tersebut, hipotesis alternatif diterima dan hipotesis nihil ditolak. Dapat disimpulkan bahwa ada pengaruh yang signifikan pengaruh kecerdasan emosional terhadap motivasi belajar matematika siswa kelas IV SD Negeri 1 Ngulankulon.
\end{abstract}

Kata kunci: Kecerdasan, Emosional, Motivasi Belajar, Matematika

\title{
Pendahuluan
}

Pendidikan merupakan sarana untuk meningkatkan Sumber Daya Manusia (SDM) dalam menghadapi permasalahan dan perubahan di era global yang semakin canggih dengan tujuan mencerdaskan kehidupan anak bangsa. ${ }^{1}$ Sedangkan menurut UU No.20 Tahun 2003 pasal 1 ayat 1 "Pendidikan adalah usaha sadar dan terencana untuk mewujudkan suasana belajar dan proses pembelajaran agar peserta didik secara aktif mengembangkan potensi dirinya untuk memiliki kekuatan spiritual keagamaan, pengendalian diri, kepribadian,

\footnotetext{
${ }^{1}$ Mahsun, M., \& Koiriyah, M. (2019). Meningkatkan Keterampilan Membaca melalui Media Big Book pada Siswa Kelas IA MI Nurul Islam Kalibendo Pasirian Lumajang. Bidayatuna: Jurnal Pendidikan Guru Mandrasah Ibtidaiyah, 2(01), 60-78. Retrieved from http:/ / www.ejournal.iaisyarifuddin.ac.id/index.php/bidayatuna/article/view/3 $\underline{61}$
} 
kecerdasan, akhlak mulia, serta keterampilan yang diperlukan dirinya, masyarakat, bangsa dan negara." Jadi menurut para ahli pendidikan adalah suatu sarana untuk meningkatkan dan mengembangan potensi dirinya dalam usaha yang terencana dengan tujuan untuk mencerdasakan kehidupan anak bangsa. Dalam pendidikan terdapat kegiatan belajar mengajar sebagai pokoknya, komponen utama yang berperan dalam kegiatan belajar mengajar yaitu guru dan peserta didik. Oleh karena itu sekolah merupakan rumah kedua setelah kehidupan mereka bersama orang tua dan saudaranya di rumah, dimana mereka dapat bermain dan belajar. ${ }^{2}$ Berdasarkan hasil observasi yang dilakukan di SDN 1 Ngulankulon, fenomena yang terjadi di dunia sekolah sekarang ini bahwa dalam pembelajaran matematika, peserta didik memiliki motivasi belajar yang relatif rendah. Kebanyakan dari mereka saat pelajaran berlangsung mayoritas siswanya mengantuk. Akan tetapi, pada dasarnya setiap siswa memiliki motivasi yang berbeda-beda. Perilaku yang ditunjukkan oleh peserta didik melalui emosi yang ada dalam dirinya. Adapun tujuan penelitian ini berdasarkan masalah yang ada yaitu untuk mengetahui tingkat kecerdasan emosional siswa kelas IV SD Negeri 1 Ngulankulon, untuk mengetahui motivasi belajar matermatika siswa kelas IV SD Negeri 1 Ngulankulon dan untuk mengetahui pengaruh kecerdasan emosional terhadap motivasi belajar matematika siswa kelas IV SDN 1 Ngulankulon.

Adapun peneliti sebelumnya dilakukan oleh Zhaelani pada tahun 2018 dengan judul "Pengaruh Kecerdasan Emosi dan Persepsi Pola Asuh Permisif Terhadap Motivasi Belajar Siswa Kelas IV SD". Hasil penelitian menunjukkan bahwa ada hubungan yang signifikansi antara kecerdasan emosional dan persepsi pola asuh permisif dengan motivasi belajar siswa kelas IV SD. Penelitian yang senada dilakukan oleh Faizi pada tahun 2018 dengan judul "Pengaruh Kecerdasan Emosional Terhadap Motivasi Belajar Matematika Siswa Kelas IV Sekolah Dasar Islam Babussalam Kecamatan Durenan Kabupaten Trenggalek Tahun Ajaran 2017/2018". Hasil penelitian menunjukkan bahwa ada pengaruh kecerdasan emosional terhadap motivasi belajar Matematika Siswa Kelas IV

\footnotetext{
${ }^{2}$ Sayyidi, S., \& Sidiq, M. (2020). Reaktualisasi Pendidikan Karakter di Era Disrupsi. Bidayatuna: Jurnal Pendidikan Guru Mandrasah Ibtidaiyah, 3(01), 105-124.
} 
Sekolah Dasar Islam Babussalam Kecamatan Durenan Kabupaten Trenggalek. Berdasarkan uraian di atas, peneliti tertarik untuk mengangkat judul yaitu “Pengaruh Kecerdasan Emosional Terhadap Motivasi Belajar Matematika Siswa Kelas IV SD Negeri 1 Ngulankulon Tahun Pelajaran 2019/2020".

\section{Kajian Konseptual}

Belajar merupakan proses yang dilakukan setiap individu selama hidupnya. ${ }^{3}$ Sedangkan menurut Syah belajar adalah kegiatan yang fundamental dalam pelaksanaan setiap jenis dan jenjang pendidikan. ${ }^{4}$ Berdasarkan uraian di atas dapat disimpulkan bahwa belajar merupakan suatu proses perubahan yang dilalui setiap manusia sebagai hasil dari pengalaman antara individu dengan lingkungan. Menurut Setyawan dan Simbolon "Matematika adalah mata pelajaran yang berasal dari konsepkonsep abstrak yang dikembangkan menurut aturan yang logis."5 Sedangkan Wiyono, dkk berpendapat "Matematika adalah salah satu mata pelajaran yang memiliki peranan penting, baik kehidupan akademis maupun kehidupan sehari-hari. Matematika adalah metode berpikir logis yang artinya matematika merupakan suatu cara yang digunakan dalam berpikir logis". 6 Berdasarkan uraian diatas, maka dapat disimpulkan bahwa motivasi belajar matematika adalah kegiatan belajar yang termotivasi berupa perubahan dalam bentuk sikap, pengetahuan dan

${ }^{3}$ Karwati, \& Priansa. 2015. Manajemen Kelas. Bandung: Alfabeta.

${ }^{4}$ Syah, Muhibbin. 2015. Psikologi Belajar. Jakarta: PT Bumi Aksara.

5 Setyawan \& Simbolon. 2018. Pengaruh Kecerdasan Emosional Terhadap Hasil Belajar Matematika Siswa SMK Kansai Pekanbaru, (Online), (http://www.jurnal.untirta.ac.id/index.php/JPPM/article/view/2980/2311), diakses tanggal 18 Desember 2019.

6 Wiyono, dkk. 2018. Pengaruh Kecerdasan Emosional Terhadap Hasil Belajar Matematika Siswa Kelas VIII MTS Negeri 1 Kendari., (Online), (http://ojs.uho.ac.id/index.php/JPPM/article/view/9121), diakses tanggal 18 Desember 2019. 
keterampilan dalam hal tentang bilangan, bangun, dan logika yang saling berkaitan serta dapat diukur atau diamati.

Dalam hal beradaptasi, interaksi dan berkomunikasi dengan masyarakat seseorang harus pandai dalam hal menggunakan dan mengontrol emosi dalam kehidupan sehari-hari.7 Emosi berasal dari Bahasa Latin yaitu emovere artinya bergerak menjauh. Arti kata tersebut bahwa kecenderungan bertindak merupakan hal mutlak dalam emosi. Menurut Rohiat dalam Priambada adapun macam-macam emosi manusia yang dalam kehidupan sehari-hari muncul dan dikenal oleh masyarakat luas dapat didefinisikan diantaranya yaitu amarah, kesedihan, ketakutan, kenikmatan, cinta, terkejut, jengkel, malu. ${ }^{8}$ Berdasarkan macam-macam emosi di atas, manusia dalam kehidupannya sehari-hari memiliki macammacam emosi yang berbeda-beda pada setiap orang yang disebabkan oleh faktor yang berbeda juga atau beragam sesuai dengan keadaan yang terjadi di lingkungan masyarakat. Menurut Rohiat dalam Priambada, "mengemukakan emosi dan pikiran adalah dua bagian dari satu keseluruhan. ${ }^{9}$ Oleh karena itu, istilah baru yang diciptakan untuk menggambarkan kecerdasan hati EQ. EQ bertujuan meningkatkan ukuran standart kekuatan otak yaitu IQ. IQ dan EQ adalah sumber sinergis. Tanpa salah satu unsur-unsur yang lain menjadi tidak lengkap dan efektif, IQ tanpa EQ bisa saja mencetak nilai A pada ujian, tetapi tidak akan membuat seseorang dapat maju dalam hidup. EQ bertanggung jawab untuk penghargaan diri sendiri, kesadaran diri sendiri, kepekaan sosial, dan adaptasi sosial."

\footnotetext{
${ }^{7}$ Rachman, R. (2020). Kebijakan Pendidikan Anak Berkebutuhan Khusus di Surabaya dalam Perspektif Islam. Bidayatuna: Jurnal Pendidikan Guru Mandrasah Ibtidaiyah, 3(01), 125-143.

8 Priambada, R. 2019. Hubungan Kecerdasan Emosional Dengan Prestasi Belajar Pendidikan Kewarganegaraan Siswa Kleas X Di SMK Negeri 1 Pogalan Tahun Pelajaran 2019/2020. Skripsi. Trenggalek : STKIP PGRI Trenggalek.

9 Priambada, R. 2019. Hubungan Kecerdasan....
} 
Perbedaan yang saling mendasar antara kecerdasan intelektual (IQ) dan kecerdasan emosional (EQ) adalah bahwa kecerdasan emosional (EQ) tidak dipengaruhi oleh faktor keturunan, sehingga membuka kesempatan bagi orang tua dan pendidik untuk melanjutkan yang telah tersedia oleh alam agar anak mempunyai peluang lebih besar untuk meraih kesuksesan. Mengutif Goleman dalam Masaong dan Tilomi “kecerdasan emosional merupakan cara seseorang untuk memotivasi diri sendiri dalam mengendalikan sikap frustasi yang dapat melumpuhkan kemampuan berfikir."10 Sedangkan menurut Goleman dalam Tridhonanto "kecerdasan emosional merupakan kemampuan yang dimiliki manusia dalam memotivasi diri, bertahan mengadapi rintangan, mengendalikan emosi dan menunda kepuasan, serta mengatur diri."11 Jadi dapat disimpulkan, kecerdasan emosional adalah kemampuan untuk memotivasi diri sendiri, mengelola emosi dengan baik dan dalam hubungan dengan orang lain.

Dari definisi diatas, maka kecerdasan emosional adalah kemampuan seseorang dalam pengontrolan atau pengendalian emosi yang digambarkan dengan mampu mengatur gejolak emosi yang terjadi di dalam diri, mampu memahami emosi orang lain dan memiliki kematangan yang berfikir yang didasarkan logika dan perasaan. Setiap siswa atau individu memiliki beragam ciri-ciri kecerdasan emosional dalam dirinya. ${ }^{12}$ Menurut Maliki dalam Kadeni ada beberapa ciri atau karakteristik siswa atau individu yang mempunyai kecerdasan emosional yang tinggi dan memuaskan yaitu memiliki Empati, mengungkapkan dan memahami perasaan, mengendalikan amarah, memiliki kemandirian,

\footnotetext{
10 Goleman. 2015. Kecerdasan Emosional. Jakarta : Gramedia Pustaka Utama

11 Zahriati dan Fatimah Ibda, 2016, Kecerdasan Emosi Mahasiswa Prodi Manajemen Pendidikan Islam Fakultas Tarbiyah dan Keguruan UIN Ar-Raniry, Jurnal Intelektualita, Vol 4, No 1 2016, Aceh: Uin Ar-Raniry, https://jurnal.arraniry.ac.id/index.php/intel/article/view/3941.

12 Faizi, M. S. 2018. Pengaruh Kecerdasan Emosional Terhadap Motivasi Belajar Matematika Siswa Kelas IV Sekolah Dasar Islam Babussalam Kecamatan Durenan Kabupaten Trenggalek. Skripsi. Tulungagung : Jurnal Ilmiah Pendidikan Dasar.
} 
menyesuaikan diri, disukai oleh orang banyak, memecahkan masalah, semangat setiakawanan, hormat menghormati antar sesama. ${ }^{13}$ Kecerdasan emosional merujuk pada kemampuan-kemampuan seseorang dalam mengendalikan diri motivasi diri dan berempati. Terdapat lima unsur dalam kecerdasan emosional meliputi, kesadaran diri, mampu mengelola emosi, motivasi diri, mampu berempati, dan mampu menjalin sosial dengan orang lain. ${ }^{14}$ Setiap manusia memiliki cara untuk mencapai kesuksesan masingmasing. Menurut Goleman ada 5 indikator kecerdasan emosional yang menjadi langkah bagi manusia untuk mencapai kesuksesan yaitu kesadaran diri, pengaturan diri, motivasi, mengenali emosi orang lain, keterampilan sosial. ${ }^{15}$

\section{Metode}

Penelitian survei ini digunakan karena untuk mengambil suatu generalisasi dari pengamatan yang tidak mendalam. Penelitian survei adalah penelitian yang dilakukan pada populasi besar dan kecil, data yang digunakan dari data sampel yang diambil dari populasi yang digunakan. Populasi penelitian ini adalah siswa kelas IV dengan jumlah 21 siswa dan keseluruhan populasi dijadikan sampel karena sampling yang digunakan adalah sampling jenuh. Sedangkan jenis penelitian ini adalah penelitian kuantitatif. Teknik yang digunakan untuk mengumpulkan data yaitu observasi dan angket. Sebelum angket dibagikan kepada responden, terlebih dahulu angket di uji coba berupa uji validitas dan uji reliabilitas ke 30 responden tujuannya untuk mengetahui valid dan reliabelnya angket yang digunakan untuk penelitian. Pada penelitian ini menggunakan SPSS versi 23.00 karena data yang diambil

\footnotetext{
13 Kadeni, 2014, Pentingnya Kecerdasan Emosional dalam Pembelajaran, Jurnal equilibrium Vol 2, No 1 (2014), Madiun: Universitas PGRI Madiun, http://ejournal.unipma.ac.id/index.php/equilibrium/article/view/601

14 Faizi, M. S. 2018. Pengaruh Kecerdasan Emosional Terhadap Motivasi Belajar Matematika Siswa Kelas IV Sekolah Dasar Islam Babussalam Kecamatan Durenan Kabupaten Trenggalek. Skripsi. Tulungagung : Jurnal Ilmiah Pendidikan Dasar.

${ }^{15}$ Goleman. 2015. Kecerdasan Emosional.
} 
berupa data kuantitatif dan analisis yang digunakan yaitu korelasi product moment. Teknik analisis data dalam penelitian ini yaitu teknik deskriptif karena untuk mendeskripsikan hasil data yang terkumpul. Dan uji hipotesis untuk mengetahui adakah pengaruh atau tidaknya suatu variabel.

Adapun prosedur penelitian yang dilakukan oleh peneliti dibagi menjadi tiga tahap yaitu pertama tahap persiapan merupakan suatu hal yang penting dalam menyusun penelitian. Hal tersebut berpengaruh pada pelaksanaan penyusunan penelitian dan akan menjamin kelancaran dalam pelaksanaan penelitian. Ada pun tahap persiapan ini meliputi, mengajukan judul penelitian kepada dosen pembimbing, sebelum melakukan penelitian, peneliti menyerahkan surat ijin dari kampus ke sekolah untuk melaksanakan penelitian, mengkonsultasikan dengan pihak sekolah mengenai waktu penelitian, menentukan populasi dan sampel yang akan digunakan sebagai responden penelitian, membuat instrumen penelitian berupa angket atau kuesioner dan observasi, melakukan konsultasi kepada dosen pembimbing mengenai intrumen yang dibuat, melakukan uji coba instrument dan menganalisis hasil uji coba instrumen untuk mengetahui layak atau tidaknya instrumen tersebut. Kedua tahap pelaksanaan, setelah mendapatkan ijin untuk mengadakan penelitian melalui arahan dari dosen pembimbing, peneliti mengadakan kegiatan diantaranya pelaksanakan penelitian pada siswa kelas IV SD Negeri 1 Ngulankulon, observasi dan memberikan angket atau kuesioner kepada siswa dan mengumpulkan data hasil angket dan observasi dengan instrumen yang telah ditetapkan. Ketiga tahap pelaporan, pada tahap ini peneliti menyusun laporan berbentuk karya ilmiah yaitu, mengolah data menggunakan metode analisis data yang 
telah ditentukan, menarik kesimpulan berdasarkan hasil analisis data yang telah dilakukan dan melaporkan hasil penelitian. ${ }^{16}$

\section{Hasil}

Data yang peroleh dari lokasi penelitian di SD Negeri 1 Ngulankulon pada tanggal 02 sampai 31 Mei 2020 dengan menggunakan metode dan instrumen penelitian yang telah ditetapkan. Subjek yang diteliti sebanyak 21 siswa. Adapun data yang akan dideskripsikan terdiri dari observasi dan data kecerdasan emosional (variable X) dan data motivasi belajar matematika (variable Y). Berdasarkan hasil observasi yang telah dibuat oleh peneliti, adapun sajian data yang diteliti data observasi ini dibuat untuk memperkuat data angket atau kuesioner. Berikut ini data hasil observasi yang diperoleh peneliti.

Tabel 1. Lembar observasi

\begin{tabular}{|c|c|c|c|}
\hline \multirow[t]{2}{*}{ Indikator } & \multicolumn{2}{|c|}{ Dilakukan } & \multirow[t]{2}{*}{ Keterangan } \\
\hline & Iya & Tidak & \\
\hline $\begin{array}{l}\text { Keadaan lingkungan } \\
\text { dan letak geografis SD } \\
\text { Negeri } 1 \text { Ngulankulon. }\end{array}$ & $\sqrt{ }$ & & $\begin{array}{l}\text { Lingkungan di SD Negeri } 1 \text { Ngulankulon } \\
\text { sangat bersih dan nyaman. Siswa dapat } \\
\text { bermain leluasa dengan halaman yang } \\
\text { luas. }\end{array}$ \\
\hline \multicolumn{4}{|c|}{ Kondisi Umum SD Negeri 1 Ngulankulon. } \\
\hline a. Guru & $\sqrt{ }$ & & Kondisi Guru Baik \\
\hline b. Peserta Didik & $\sqrt{ }$ & & Kondisi Siwa Baik \\
\hline
\end{tabular}

(Sumber : Peneliti, 2020)

Tabel 2. Subjek Peserta Didik Kelas IV

\begin{tabular}{|c|c|c|c|}
\hline Aspek yang Diamati & Terlihat & Tidak & Keterangan \\
\hline $\begin{array}{l}\text { Peserta didik } \\
\text { melaksanakan kegiatan } \\
\text { Pembelajaran di dalam } \\
\text { kelas. }\end{array}$ & $\sqrt{ }$ & & $\begin{array}{l}\text { Peserta didik melakukan } \\
\text { pembelajaran dengan tertib, } \\
\text { nyaman dan tenang. }\end{array}$ \\
\hline $\begin{array}{l}\text { Peserta didik dapat } \\
\text { mengendalikan emosi saat } \\
\text { pembelajaran matematika. }\end{array}$ & $\sqrt{ }$ & & $\begin{array}{l}\text { Peserta didik mampu } \\
\text { mengendalikan emosi pada saat } \\
\text { pembelajaran matematika. }\end{array}$ \\
\hline $\begin{array}{l}\text { Peserta didik mampu } \\
\text { termotivasi dalam } \\
\text { pembelajaran matematika. }\end{array}$ & $\sqrt{ }$ & & $\begin{array}{l}\text { Peserta didik dapat termotivasi } \\
\text { saat pembelajaran matematika } \\
\text { berlangsung. }\end{array}$ \\
\hline
\end{tabular}

${ }^{16}$ Arikunto, S. 2013. Prosedur Penelitian Suatu Pendekatan Praktik. Jakarta: Rineka Cipta. 


\begin{tabular}{|lccl|}
\hline \multicolumn{1}{|c}{ Aspek yang Diamati } & Terlihat & Tidak & \multicolumn{1}{c|}{ Keterangan } \\
\hline $\begin{array}{l}\text { Peserta didik ingin } \\
\text { membantu teman yang }\end{array}$ & & & Rasa kepeduli sesama siswa \\
kesulitan dalam belajar & $\sqrt{ }$ & & $\begin{array}{l}\text { juga ditunjukan siswa saat } \\
\text { temannya mengalami kesulitan } \\
\text { matematika. }\end{array}$ \\
dalam belajar matematika
\end{tabular}

(Sumber : Peneliti, 2020)

Data variabel kecerdasan emosional merupakan data yang bersumber dari siswa kelas IV SD Negeri 1 Ngulankulon tahun pelajaran 2019/2020 yang diperoleh melalui metode penyebaran angket pada sampel penelitian yang berjumlah 21 siswa. Berdasarkan analisis statistik deskriptif dengan menggunakan aplikasi SPSS versi 23.00 sebagaimana lampiran analisis data kecerdasan emosional dapat dilihat pada tabel 3.

Tabel 3. Data Deskriptif Variabel Kecerdasan Emosional

\begin{tabular}{|c|c|c|c|c|}
\hline \multicolumn{5}{|c|}{ Descriptive Statistics } \\
\hline & $\mathrm{N}$ & Minimum & Maximum & Mean \\
\hline KecerdasanEmosional & 21 & 54 & 70 & 64,14 \\
\hline Valid N (listwise) & 21 & & & \\
\hline
\end{tabular}

Berdasarkan hasil dari tabel 3 tersebut dapat diketahui bahwa nilai rata-rata kecerdasan emosional diperoleh siswa skor yang tertinggi adalah 70 skor terendah adalah 54, dan rata-rata skor yang diperoleh adalah 64.14. Data hasil penelitian menunjukkan kecerdasan emosional siswa kelas IV SD Negeri 1 Ngulankulon tahun pelajaran 2019/2020 diperoleh rata-rata 64.14 yang memiliki kecenderungan kategori sedang, secara terperinci dapat dilihat pada tabel 4 .

Tabel 4. Distribusi Frekuensi Kecerdasan Emosional

\begin{tabular}{cccc}
\hline Kategori & Rentang Nilai & Frekuensi & Persentase \\
\hline Sangat Tinggi & $69-71$ & 3 & $14 \%$ \\
\hline Tinggi & $66-68$ & 8 & $38 \%$ \\
\hline Sedang & $63-65$ & 3 & $14 \%$ \\
\hline Rendah & $60-62$ & 4 & $19 \%$ \\
\hline Sangat Rendah & $57-59$ & 2 & $10 \%$ \\
\hline & $54-56$ & 1 & $5 \%$ \\
\hline & & $\mathbf{2 1}$ & $\mathbf{1 0 0 \%}$ \\
\hline
\end{tabular}

(Sumber : Peneliti, 2020) 
Adapun tambahan penjelasan dari variabel kecerdasan emosional (X) siswa kelas IV SD Negeri 1 Ngulankulon dalam bentuk diagram sebagai berikut.

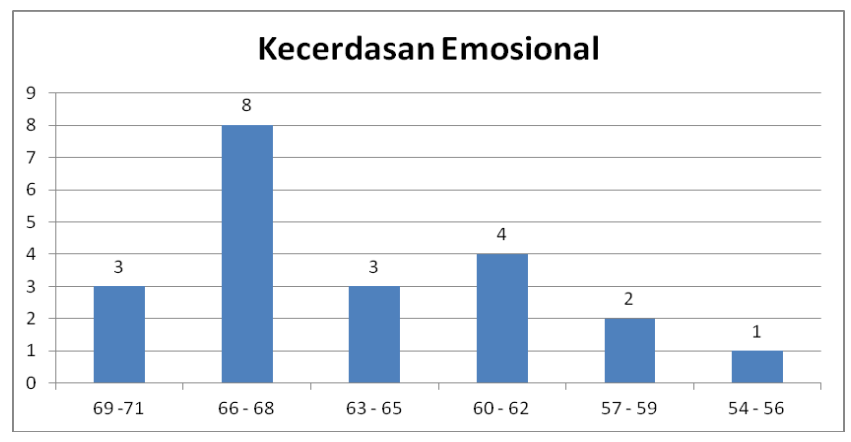

Gambar 1. Distribusi Frekuensi Kecerdasan Emosional (Sumber : Peneliti, 2020)

Berdasarkan tabel 4 Gambar 1 dapat diketahui bahwa nilai kecerdasan emosional siswa kelas IV SD Negeri 1 Ngulankulon yang ada pada kategori sangat tinggi (rentang nilai 69-71) terdapat 3 siswa, kategori tinggi (rentang nilai 66-68) terdapat 8 siswa, kategori sedang (rentang nilai 63-65) terdapat 3 siswa dan kategori rendah (rentang nilai 60-62) terdapat 4 siswa, serta kategori sangat rendah (rentang nilai 57-59) terdapat 2 siswa dan yang terakhir rentan nilai 54-56 terdapat 1 siswa. Sehingga dapat disimpulkan siswa paling banyak mendapatkan nilai kecerdasan emosional kategori tinggi yaitu sebesar 38\%.

Data motivasi belajar matematika merupakan data yang bersumber dari siswa kelas IV SD Negeri 1 Ngulankulon yang diperoleh melalui metode penyebaran angket. Berdasarkan analisis deskriptif dengan menggunakan aplikasi IBM SPSS versi 23.00. dapat dilihat pada tabel 5 .

Tabel 5. Data Deskriptif Variabel Motivasi Belajar Matematika Descriptive Statistics

\begin{tabular}{lrrrc}
\hline & N & Minimum & Maximum & Mean \\
\hline MotivasiBelajarMatematika & 21 & 115 & 140 & 129,00 \\
\hline Valid N (listwise) & 21 & & & \\
\hline
\end{tabular}

(Sumber : Peneliti, 2020)

Berdasarkan tabel 5 tersebut menunjukkan bahwa skor motivasi belajar matematika siswa yang tertinggi 140, terendah 115 , dan rata-rata 
skor yang diperoleh adalah 129.00. Data hasil penelitian menunjukkan motivasi belajar matematika siswa kelas IV SD Negeri 1 Ngulankulon diperoleh rata-rata 129.00 yang memiliki kecenderungan kategori cukup. Secara terperinci dapat dilihat pada tabel 6 .

Tabel 6. Distribusi Frekuensi Motivasi Belajar Matematika

\begin{tabular}{|cccc|}
\hline Kategori & Rentang Nilai & Frekuensi & Persentase \\
\hline Sangat Baik & $135-140$ & 2 & $10 \%$ \\
\hline Baik & $130-134$ & 9 & $43 \%$ \\
\hline Cukup & $125-129$ & 6 & $29 \%$ \\
\hline Kurang Baik & $120-124$ & 2 & $10 \%$ \\
\hline Sangat Kurang Baik & $115-119$ & 2 & $10 \%$ \\
\hline Total & $\mathbf{2 1}$ & $\mathbf{1 0 0} \%$ \\
\hline
\end{tabular}

(Sumber : Peneliti, 2020)

Adapun tambahan penjelasan dari variabel motivasi belajar matematika (Y) siswa kelas IV SD Negeri 1 Ngulankulon dalam bentuk diagram sebagai berikut.

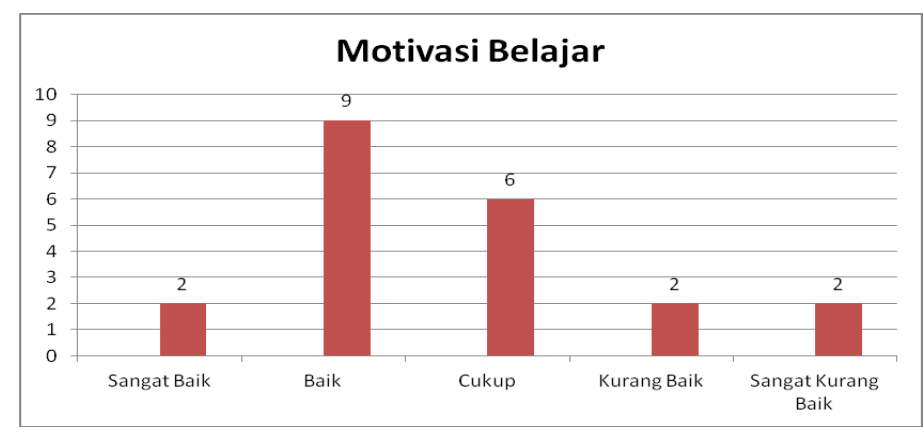

Gambar 2. Distribusi Frekuensi Motivasi Belajar Matematika (Sumber : Peneliti, 2020)

Berdasarkan tabel 6 dan gambar 2 dapat diketahui bahwa nilai motivasi belajar matematika siswa kelas IV SD Negeri 1 Ngulankulon yang ada pada kategori sangat baik (rentang nilai 135 - 140) terdapat 2 siswa, kategori baik (rentang nilai 130 - 134) terdapat 9 siswa, kategori cukup (rentang nilai 125 - 129) terdapat 6 siswa dan kategori kurang baik (rentang nilai 120 - 124) terdapat 2 siswa, serta kategori sangat kurang baik (rentang nilai 115-119) terdapat 2 siswa. Sehingga dapat disimpulkan 
siswa paling banyak mendapatkan nilai motivasi belajar matematika kategori baik yaitu sebesar $43 \%$.

Penelitian ini menggunakan normalitas Test Of Normality Kolmogorov-Smirnov dengan program SPSS versi 23.00. berikut ini hasil dari uji normalitas.

Tabel 7. Uji Normalitas

One-Sample Kolmogorov-Smirnov Test

\begin{tabular}{|l|l|r|}
\hline \multicolumn{2}{|c|}{} & Unstandardized Residual \\
\hline $\mathrm{N}$ & 21 \\
Normal Parametersa,b & Mean &, 0000000 \\
& Std. Deviation & 1,62002565 \\
Most Extreme & Absolute &, 181 \\
Differences & Positive &, 181 \\
& Negative &,- 113 \\
Test Statistic & &, 181 \\
Asymp. Sig. (2-tailed) &, $070^{\mathrm{c}}$ \\
\hline
\end{tabular}

a. Test distribution is Normal.

b. Calculated from data.

(Sumber : Peneliti, 2020)

Berdasarkan tabel 7 hitungan uji normalitas diatas dapat diketahui bahwa nilai signifikansi penelitian ini 0,070, bahwa jika signifikansi > data berdistribusi normal, maka $0,070>0,05$. Jadi kesimpulannya data penelitian ini berdistribusi normal.

Analisis regresi linier sederhana ini digunakan untuk mengetahui ada tidaknya pengaruh kecerdasan emosional terhadap motivasi belajar. Berikut hasil dari analisis regresi linier sederhana dalam penelitian, untuk lebih lengkapnya berada pada lampiran.

Tabel 8. Perhitungan Regresi Linier Sederhana

\begin{tabular}{|c|c|c|c|c|c|}
\hline \multirow[b]{3}{*}{ Model } & \multicolumn{2}{|c|}{ Coefficients $^{a}$} & \multirow[b]{2}{*}{$\begin{array}{c}\text { Standardized } \\
\text { Coefficients }\end{array}$} & \multirow[b]{3}{*}{$\mathrm{t}$} & \multirow[b]{3}{*}{ Sig. } \\
\hline & \multicolumn{2}{|c|}{$\begin{array}{c}\text { Unstandardized } \\
\text { Coefficients }\end{array}$} & & & \\
\hline & $\mathrm{B}$ & Std. Error & Beta & & \\
\hline 1 (Constant) & 40,035 & 5,249 & & 7,628 & ,000 \\
\hline KecerdasanEmosional & 1,387 & ,082 & ,969 & 16,991 & ,000 \\
\hline
\end{tabular}

a. Dependent Variable: MotivasIBelajarMatematika

(Sumber : Peneliti, 2020) 
Berdasarkan tabel 8 di atas dapat diketahui bahwa nilai Constant (a) sebesar 40,035, sedang nilai kecerdasan emosional (b/koefisien regresi) sebesar 1,387, sehingga persamaan regresinya dapat ditulis:

$\gamma=\alpha+b X$

$Y=40,035+1,387 X$

Persamaan tersebut juga dapat diterjemahkan bahwa konstanta sebesar 40,035 mengandung arti bahwa nilai konsisten variabel kecerdasan emosional adalah sebesar 40,035. Dan koefisien regresi $X$ sebesar 1,387 yang menyatakan bahwa setiap penambahan $1 \%$ nilai kecerdasan emosional, maka nilai motivasi belajar matematika bertambah sebesar 1,387 .

Cara mencari

$$
\begin{aligned}
r_{\text {tabel }}= & \left(\frac{\alpha}{2}: \mathrm{n}-\mathrm{k}-1\right) \\
& =\left(\frac{0,05}{2}: 21-1-1\right) \\
& =0,025: 19 \\
& =1,729
\end{aligned}
$$

Pengambilan keputusan pada analisis regresi sederhana ini yaitu jika nilai signifikansi < 0,05 maka dinyatakan bahwa ada pengaruh antara kecerdasan emosional $(\mathrm{X})$ terhadap motivasi belajar matematika $(\mathrm{Y})$, berdasarkan tabel 4.10 Coefficients di atas dapat diperoleh nilai signifikansi sebesar $0,000<0,05$, sehingga dapat disimpulkan bahwa variabel kecerdasan emosional $(X)$ berpengaruh terhadap motivasi belajar matematika (Y). Sedangkan nilai $\mathrm{t}$ diketahui bahwa nilai rhitung sebesar 16,991 > rtabel sebesar 1,729 sehingga dapat disimpulkan bahwa kecerdasan emosional $(X)$ berpengaruh terhadap motivasi belajar matematika $(\mathrm{Y})$.

Analisis regresi linier sederhana tersebut juga dapat digunakan utuk mengetahui seberapa besar pengaruh variabel $X$ terhadap $Y$, 
sehingga penelitian ini dapat diketahui bahwa seberapa besar pengaruh kecerdasan emosional terhadap motivasi belajar matematika siswa kelas IV SD Negeri 1 Ngulankulon. Berikut ini hasil berapa besar pengaruh variabel $X$ terhadap $Y$.

Tabel 9. Besar Pengaruh Variabel $X$ terhadap Variabel $Y$

\begin{tabular}{|l|c|c|c|c|}
\hline Model & R & R Square & Adjusted R Square & Std. Error of the Estimate \\
\hline 1 &, $969 \mathrm{a}$ &, 938 &, 935 & 1,66211 \\
\hline
\end{tabular}

a. Predictors: (Constant), KecerdasanEmosional

(Sumber : Peneliti, 2020)

Dari tabel 9 tersebut menunjukkan bahwa besarnya nilai korelasi/hubungan $(\mathrm{R})$ yaitu 0,969 . Sedangkan koefisien determinasi $(R$ Square) sebesar 0,938 dikalikan 100\% sama dengan 93,8\%, artinya besar pengaruh variabel bebas (kecerdasan emosional) terhadap variabel terikat (motivasi belajar matematika) adalah sebesar 93,8\%.

Berdasarkan hasil dari analisis data di atas dapat diketahui bahwa nilai rhitung sebesar 16,991 > rtabel sebesar 1,729 pada taraf signifikan 5\%, maka $H_{a}$ diterima dan $H_{o}$ ditolak sehingga hipotesis yang diajukan dalam penelitian ini yaitu:

$H_{a} \quad$ : Ada pengaruh antara kecerdasan emosional $(\mathrm{X})$ dengan motivasi belajar matematika (Y) siswa kelas IV SD Negeri 1 Ngulankulon. $H_{a}$ dinyatakan diterima.

$H_{o} \quad$ : Tidak ada pengaruh antara kecerdasan emosional (X) dengan motivasi belajar matematika (Y) siswa kelas IV SD Negeri 1 Ngulankulon. $H_{\circ}$ dinyatakan ditolak.

Dari hasil analisis data tersebut dapat disimpulkan bahwa ada pengaruh antara kecerdasan emosional $(X)$ dengan motivasi belajar matematika (Y) siswa kelas IV SD Negeri 1 Ngulankulon.)

\section{Pembahasan}


Berdasarkan hasil perhitungan regresi linier sederhana antara kecerdasan emosional dengan motivasi belajar diketahui bahwa $\mathrm{r}$ hitung sebesar 16,991, kemudian dikonsultasikan dengan $r_{\text {tabel }}$ pada taraf signifikansi $5 \%=1,729$, maka $r_{\text {hitung }}$ lebih besar dari $r_{\text {tabel }}$ sehingga dapat dikatakan bahwa kecerdasan emosional mempunyai pengaruh terhadap motivasi belajar matematika.

Pengaruh kecerdasan emosional pada dasarnya bertujuan untuk mengetahui adakah pengaruh kecerdasan emosional $(X)$ dengan motivasi belajar matematika (Y) siswa kelas IV SD Negeri 1 Ngulankulon. Dengan pernyataan tersebut terjawab dan terbukti dari hasil uji koefisien determinasi yang menyatakan bahwa ada pengaruh antara kecerdasan emosional (variabel X) dengan motivasi belajar matematika (variabel Y) siswa kelas IV SD Negeri 1 Ngulankulon dan besar pengaruh variabel $X$ (kecerdasan emosional) terhadap variabel Y (motivasi belajar matematika) sebesar 93,8\%. Jadi dapat disimpulkan bahwa siswa kelas IV SD Negeri 1 Ngulankulon dalam belajarnya, kecerdasan emosionalnya dapat berpengaruh dengan motivasi belajar matematika.

\section{Kesimpulan}

Berdasarkan dari hasil penelitian analisis data dan pembahasan yang sudah dibahas, dapat disimpulkan bahwa:

1. Kecerdasan emosional peserta didik kelas IV SD Negeri 1 Ngulankulon berada pada kategori sedang dengan persentase $14 \%$.

2. Motivasi belajar matematika peserta didik kelas IV SD Negeri 1 Ngulankulon berapa pada kategori cukup dengan persentase $29 \%$.

3. Setelah dilakukan analisis data diketahui bahwa adanya pengaruh yang cukup signifikan dengan hasil $r$ hitung $=16,991$ dan dikonsultasikan dengan nilai $\mathrm{t}$ tabel $=1,729$. Persamaan regresinya yaitu $Y=40,035+1,387 X$. Hal ini menunjukkan bahwa koefisien regresi $X$ sebesar 1,387 yang menyatakan bahwa setiap penambahan 
1\% nilai kecerdasan emosional, maka nilai motivasi belajar bertambah sebesar 1,387. Hubungan antara kecerdasan emosional terhadap motivasi belajar matematika memiliki nilai sebesar 0,938. Besarnya pengaruh dari kecerdasan emosional terhadap motivasi belajar dilihat dari koefisien determinasi ( $R$ Square) yang dikalikan 100\%, sehingga dapat diketahui besar pengaruh kecerdasan emosional (variabel $\mathrm{X} /$ bebas) terhadap motivasi belajar matematika (variabel $\mathrm{Y} /$ terikat) adalah sebesar 93,8\%. Hal tersebut dapat dijadikan sebagai pertimbangan bahan evaluasi untuk pihak sekolahan agar siswa mengendalikan kecerdasan emosionalnya dengan baik sehingga siswa dapat termotivasi dalam belajar matematika.

\section{Daftar Pustaka}

Arikunto, S. 2013. Prosedur Penelitian Suatu Pendekatan Praktik. Jakarta: Rineka Cipta.

Faizi, M. S. 2018. Pengaruh Kecerdasan Emosional Terhadap Motivasi Belajar Matematika Siswa Kelas IV Sekolah Dasar Islam Babussalam Kecamatan Durenan Kabupaten Trenggalek. Skripsi. Tulungagung : Jurnal Ilmiah Pendidikan Dasar.

Goleman. 2015. Kecerdasan Emosional. Jakarta : Gramedia Pustaka Utama.

Karwati, \& Priansa. 2015. Manajemen Kelas. Bandung: Alfabeta.

Kuncorowati, dkk. 2019. Pedoman Penyusunan Skripsi cetakan ke 1 STKIP PGRI Trenggalek.. Trenggaliek: STKIP PGRI Trenggalek

Mahsun, M., \& Koiriyah, M. (2019). Meningkatkan Keterampilan Membaca melalui Media Big Book pada Siswa Kelas IA MI Nurul Islam Kalibendo Pasirian Lumajang. Bidayatuna: Jurnal Pendidikan Guru Mandrasah Ibtidaiyah, 2(01), 60-78. Retrieved from http://www.ejournal.iaisyarifuddin.ac.id/index.php/bidayatu na/article/view/361

Pendidikan Nasional, 2003. (Online).

Priambada, R. 2019. Hubungan Kecerdasan Emosional Dengan Prestasi Belajar Pendidikan Kewarganegaraan Siswa Kleas X Di SMK Negeri 1 Pogalan Tahun Pelajaran 2019/2020. Skripsi. Trenggalek : STKIP PGRI Trenggalek. 
Rachman, R. 2020. Kebijakan Pendidikan Anak Berkebutuhan Khusus di Surabaya dalam Perspektif Islam. Bidayatuna: Jurnal Pendidikan Guru Mandrasah Ibtidaiyah, 3(01), 125-143. http://www.ejournal.iaisyarifuddin.ac.id/index.php/bidayatuna/a rticle/view/518

Setyawan \& Simbolon. 2018. Pengaruh Kecerdasan Emosional Terhadap Hasil Belajar Matematika Siswa SMK Kansai Pekanbaru, (Online), (http://www.jurnal.untirta.ac.id/index.php/JPPM/article/view/29 80/2311), diakses tanggal 18 Desember 2019.

Sayyidi, S., \& Sidiq, M. 2020. Reaktualisasi Pendidikan Karakter di Era Disrupsi. Bidayatuna: Jurnal Pendidikan Guru Mandrasah Ibtidaiyah, 3(01), 105-124. http://www.ejournal.iaisyarifuddin.ac.id/index.php/bidayatuna/a rticle/view/520

Syah, Muhibbin. 2015. Psikologi Belajar. Jakarta: PT Bumi Aksara.

Wiyono, dkk. 2018. Pengaruh Kecerdasan Emosional Terhadap Hasil Belajar Matematika Siswa Kelas VIII MTS Negeri 1 Kendari., (Online), (http://ojs.uho.ac.id/index.php/JPPM/article/view/9121), diakses tanggal 18 Desember 2019. 